\title{
Designation of Neotype Strains and of Biotype Reference Strains for Species of the Genus Brucella Meyer and Shaw
}

\author{
MARGARET E. MEYER and W. J. B. MORGAN \\ School of Veterinary Medicine, University of California, Davis, California, and \\ Central Veterinary Laboratory, Weybridge, Surrey, England
}

\begin{abstract}
Among the five generally recognized species in the genus Brucella Meyer and Shaw, a type strain exists only for Brucella neotomae Stoenner and Lackman. Described herein are the characteristics of $B$. abortus (Schmidt and Weis) Meyer and Shaw, strain 544 (ATCC 23488); B. suis Huddleson, strain 1330 (ATCC 23444); B. melitensis (Hughes) Meyer and Shaw, strain 16M (ATCC 23456); and B. ovis Buddle strain 6690 (ATCC 25840). Each of these strains has feat ures similar to those reported for the original isolates of the species, each simultaneously fits the revised species descriptions and, when viewed in toto, these strains reflect the current concept of this genus. Thus, in accordance with the recommendations of the International Subcommittee on the Taxonomy of the Genus Brucella, these strains here are designated as the neotype strains of these species. Because three of the species in this genus are divided into biotypes that are of epidemiological significance we have, again at the recommendation of the International Subcommittee, selected a representative strain for each biotype for use as a reference. The characteristics of each of the reference strains are also described herein.
\end{abstract}

At its meeting in Mexico City in 1970, the Subcommittee on the Genus Brucella of the International Committee on Nomenclature of Bacteria recommended the recognition of five species in this genus, viz., Brucella abortus, B. melitensis, B. neotomae, $B$. ovis, and $B$. suis. The Subcommittee also recommended that neotype strains be proposed for each of the species that lacks an extant type strain and that reference strains of each biotype within the species be designated and submitted for deposit with the American Type Culture Collection. The purpose of this paper is to designate and describe these neotype and reference strains.

\section{MATERIALS AND METHODS}

Bacterial strains. The sources of the strains reported here are listed in Table 1 .

Methods of strain characterization. Each strain was examined by the methods recommended by the Subcommittee on Taxonomy of the Genus Brucella (27). The conventional determinative methods for ascertaining the need for carbon dioxide for primary isolation, for measuring hydrogen sulfide production, and for assessing the pattern of growth on media containing basic fuchsin or thionin were performed as described by Huddleson (10). The manometric determination of metabolic pat- terns of oxidative utilization of selected amino acid and carbohydrate substrates was performed as detailed by Meyer and Cameron (18) and Meyer (19). The method described by Stinebring and Braun (28) and Meyer (14) was used for testing strain susceptibility to lysis by Brucella bacteriophage, Tbilisi strain (also known as $B$. abortus phage, strain 3 ). In addition to the original papers cited above, procedural details for performing and interpreting all the recommended tests have been presented by Meyer (15), Morgan and Gower (22), Alton and Jones (1), and the World Health Organization Expert Committee on Brucellosis (33).

\section{RESULTS}

Table 2 shows the results of the conventional determinative tests and of exposure to Brucella bacteriophage for each of the strains being designated as a neotype or as a biotype reference strain. Table 3 shows the oxidative metabolic pattern for this same array of strains. The Subcommittee on Taxonomy of the Genus Brucella has described the genus and species as follows $(11,27)$.

Genus Brucella Meyer and Shaw. "Small, nonmotile, nonsporing, gram negative coccobacilli which grow rather poorly on ordinary media or may require special media. Aerobic, no growth occurring under strictly anaerobic conditions. 
TABLE 1. Sources of neotype and biotype reference strains

\begin{tabular}{|c|c|c|c|c|}
\hline Species & Biotype & Strain designation & Host source & Geographic source \\
\hline B. abortus & $\begin{array}{l}1 \\
2 \\
3 \\
4 \\
5 \\
6 \\
7 \\
8 \\
9\end{array}$ & $\begin{array}{l}544 \\
86 / 8 / 59 \\
\text { Tulya } \\
292 \\
\text { B3196 } \\
870 \\
63175 \\
\text { None available } \\
\text { C-68 }\end{array}$ & $\begin{array}{l}\text { Bovine } \\
\text { Bovine } \\
\text { Man } \\
\text { Bovine } \\
\text { Bovine } \\
\text { Bovine } \\
\text { Bovine } \\
\text { Bovine }\end{array}$ & $\begin{array}{l}\text { England } \\
\text { England } \\
\text { Uganda } \\
\text { England } \\
\text { England } \\
\text { Africa } \\
\text { Africa } \\
\text { England }\end{array}$ \\
\hline B. melitensis & $\begin{array}{l}1 \\
2 \\
3\end{array}$ & $\begin{array}{l}16 \mathrm{M} \\
63 / 9 \\
\text { Ether }\end{array}$ & $\begin{array}{l}\text { Caprine } \\
\text { Caprine } \\
\text { Caprine }\end{array}$ & $\begin{array}{l}\text { USA } \\
\text { Turkey } \\
\text { Italy }\end{array}$ \\
\hline $\begin{array}{l}\text { B. suis } \\
\text { B. ovis }\end{array}$ & $\begin{array}{l}1 \\
2 \\
3 \\
4\end{array}$ & $\begin{array}{l}1330 \\
\text { Thomsen } \\
686 \\
40 \\
6390\end{array}$ & $\begin{array}{l}\text { Swine } \\
\text { Swine } \\
\text { Swine } \\
\text { Reindeer } \\
\text { Ovine }\end{array}$ & $\begin{array}{l}\text { USA } \\
\text { Denmark } \\
\text { USA } \\
\text { Russia } \\
\text { Africa }\end{array}$ \\
\hline
\end{tabular}

Growth often improved by $\mathrm{CO}_{2}$. Little fermentative action on carbohydrates in usual media. Urea hydrolyzed to a variable extent. Facultative intracellular parasites which produce acute and chronic infection in animals and which may cause disease in man. The $\mathrm{G}+\mathrm{C}$ content of the DNA ranges from 56 to 58 moles percent. Members of the genus comprise a closely knit and sharply demarcated genetic group as defined by DNA hybridization studies."

B. abortus (Schmidt and Weis) Meyer and Shaw. "Usually require $\mathrm{CO}_{2}$ for growth, especially on primary isolation. Usually produce moderate amounts of $\mathrm{H}_{2} \mathrm{~S}$ but may be negative. Usually grow in the presence of basic fuchsin but inhibited by thionin. Usually have A antigen predominate. Oxidize L-alanine, L-asparagine, L-glutamic acid, L-arabinose, D-galactose, D-ribose, glucose, and erythritol; do not oxidize D-xylose, L-arginine, DL-citrullin, DL-ornithine, or L-lysine. Cultures in the smooth or smooth-intermediate phase are lysed by Brucella phage $\mathrm{Tb}$ at routine test dilution. Usually pathogenic for cattle, causing abortion. Can also affect other animals, including man."

B. suis Huddleson. "Aerobic. Produce large a mounts of $\mathrm{H}_{2} \mathrm{~S}$ or none at all. Grow in the presence of thionin but usually inhibited by basic fuchsin. Usually have a antigen predominant. Oxidize L-alanine, D-alanine, L-glutamic acid, Larabinose, D-galactose, D-ribose, D-xylose, L-arginine, DL-citrulline, DL-ornithine, L-lysine, glucose and erythritol; do not oxidize L-asparagine. Not lysed by Brucella phage $\mathrm{Tb}$ at routine test dilution. Usually pathogenic for pigs but can also affect hares and other species including man."

B. melitensis (Hughes) Meyer and Shaw. "Aerobic. Produce no $\mathrm{H}_{2} \mathrm{~S}$ or no more than a trace on ordinary media. Usually grow in the presence of basic fuchsin and thionin. Usually have $M$ antigen predominant. Oxidize L-alanine, D-alanine, Lasparagine, L-glutamic acid, glucose, and erythritol. Do not oxidize L-arabinose, D-galactose, D-ribose, D-xylose, L-arginine, DL-citrulline, DLornithine, or L-lysine. Not lysed by Brucella phage $\mathrm{Tb}$ at routine test dilution. Usually pathogenic for goats and sheep, but can also affect other species, including cattle and man."

B. ovis Buddle. "Requires $\mathrm{CO}_{2}$ for growth. Does not produce $\mathrm{H}_{2} \mathrm{~S}$; grows in the presence of both basic fuchsin and thionin. Agglutinated only by anti-rough serum. Oxidize D-alanine, L-alanine, L-asparagine, and L-glutamic acid. Do not oxidize DL-ornithine, DL-citrulline, L-arginine, L-lysine, Larabinose, D-galactose, D-ribose, D-xylose, glucose, or erythritol. Pathogenic for sheep, particularly rams."

The data presented in tables 2 and 3 show that each strain being proposed as the neotype for its species has the characteristics, as measured by conventional, manometric, and phage-determinative methods, that previsely fit its species description. In addition to fitting these recently revised and expanded species descriptions, and thereby being in accord with the current concept of this genus, each strain also fits the description of the initial isolates that originally established each of the species.

\section{DISCUSSION}

The strains listed in table 4 are being designated as the neotype strains for their respective species.

Many strains of the species $B$. abortus, B. suis, and $B$. melitensis differ from their species descriptions in one or more characteristics. Neither the 
TABLE 2. Characteristics of neotype strains and biotype reference strains of Brucella species and results of conventional determinative tests

\begin{tabular}{|c|c|c|c|c|c|c|c|c|c|c|c|c|c|c|c|}
\hline \multirow{3}{*}{ Species } & \multirow{3}{*}{$\begin{array}{l}\text { Bio- } \\
\text { type }\end{array}$} & \multirow{3}{*}{$\begin{array}{c}\text { Strain } \\
\text { designation }\end{array}$} & \multirow{3}{*}{ Strain status } & \multirow{3}{*}{$\begin{array}{c}\mathrm{CO}_{2} \text { for } \\
\text { growth } \\
(+, \text { needed; } \\
-, \text { not needed })\end{array}$} & \multirow{3}{*}{$\begin{array}{c}\mathrm{H}_{2} \mathrm{~S} \\
\text { produc- } \\
\text { tion }\end{array}$} & \multicolumn{5}{|c|}{$\begin{array}{l}\text { Growth pattern } \\
\text { on dyes }\end{array}$} & \multicolumn{3}{|c|}{ Agglutination by } & \multirow{2}{*}{\multicolumn{2}{|c|}{$\begin{array}{c}\text { Phage } \\
\text { Lysis by }\end{array}$}} \\
\hline & & & & & & \multicolumn{2}{|c|}{$\begin{array}{c}\text { Basic } \\
\text { fuchsin }\end{array}$} & \multicolumn{3}{|c|}{ Thionin } & \multicolumn{2}{|c|}{$\begin{array}{l}\text { Mono- } \\
\text { specific } \\
\text { sera }\end{array}$} & \multirow{2}{*}{$\begin{array}{l}\text { Anti- } \\
\text { rough } \\
\text { serum }\end{array}$} & & \\
\hline & & & & & & 1 & 2 & 1 & 2 & 3 & $\mathbf{A}^{c}$ & $M^{c}$ & & RTD & $10^{4} \mathrm{RTD}^{d}$ \\
\hline \multirow[t]{8}{*}{ B. abortus } & 1 & 544 & $\begin{array}{l}\text { Neotype and bio- } \\
\text { type reference }\end{array}$ & + & + & + & + & - & - & - & + & - & - & + & + \\
\hline & 2 & $86 / 8 / 59$ & Biotype reference & + & + & - & - & - & - & - & + & - & - & + & + \\
\hline & 3 & Tulya & Biotype reference & - & + & + & + & + & + & - & + & - & - & + & + \\
\hline & 4 & 292 & Biotype reference & + & + & + & + & + & + & - & - & + & - & + & + \\
\hline & 5 & B3196 & Biotype reference & - & - & + & + & + & + & - & - & + & - & + & + \\
\hline & 6 & 870 & Biotype reference & - & - & + & + & + & + & - & + & - & - & + & + \\
\hline & $\begin{array}{l}7 \\
8\end{array}$ & $\begin{array}{l}63 / 75 \\
\text { None available }\end{array}$ & Biotype reference & - & + & + & + & + & + & - & + & + & - & + & + \\
\hline & 9 & C- 68 & Biotype reference & - & + & + & + & + & + & - & - & + & - & + & + \\
\hline \multirow[t]{3}{*}{ B. melitensis } & 1 & $16 \mathrm{M}$ & $\begin{array}{l}\text { Neotype and bio- } \\
\text { type reference }\end{array}$ & - & - & + & + & + & + & - & - & + & - & - & - \\
\hline & 2 & $63 / 9$ & Biotype reference & - & - & + & + & + & + & - & + & - & - & - & - \\
\hline & 3 & Ether & Biotype reference & - & - & + & + & + & + & - & + & + & - & - & - \\
\hline \multirow[t]{4}{*}{ B. suis } & 1 & 1330 & $\begin{array}{l}\text { Neotype and bio- } \\
\text { type reference }\end{array}$ & - & + & - & - & + & + & + & + & - & - & - & + \\
\hline & 2 & Thomsen & Biotype reference & - & - & - & - & + & + & - & + & - & - & - & + \\
\hline & 3 & 686 & Biotype reference & - & - & + & + & + & + & + & + & - & - & - & + \\
\hline & $\begin{array}{l}4 \\
5\end{array}$ & $\begin{array}{l}40 \\
\text { None available }\end{array}$ & Biotype reference & - & - & + & + & + & + & + & + & + & - & - & + \\
\hline B. ovis & & 6390 & Neotype & + & - & + & + & + & + & - & - & - & + & - & - \\
\hline
\end{tabular}

${ }^{a} 1,1: 25,000 ; 2,1: 50,000 ; 3,1: 100,000 ;+$, growth; - no growth.

${ }^{b}+$, Needed; - , not needed.

${ }^{c}$ A, B. abortus; M, B. melitensis.

${ }^{d}$ RTD, Routine test dilution; +, lysis; -, no lysis. 
TABLE 3. Results of manometric determination of oxidative utilization of selected substrates by neotype strains and biotype reference strains of Brucella species

\begin{tabular}{|c|c|c|c|c|c|c|c|c|c|c|c|c|c|c|c|}
\hline \multirow[b]{3}{*}{ Species } & \multirow[b]{3}{*}{$\begin{array}{l}\text { Bio- } \\
\text { type }\end{array}$} & \multirow[b]{3}{*}{ Strain designation } & \multirow[b]{3}{*}{ Strain status } & \multicolumn{12}{|c|}{ Pattern of oxidative utilization of substrates ${ }^{a}$} \\
\hline & & & & \multicolumn{7}{|c|}{ Amino acids } & \multicolumn{5}{|c|}{ Carbohydrates } \\
\hline & & & & 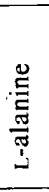 & 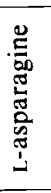 & 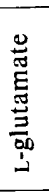 & 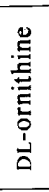 & 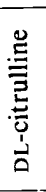 & 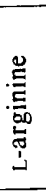 & $\frac{\mathscr{y}}{\frac{\pi}{2}}$ & 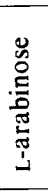 & 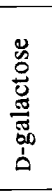 & 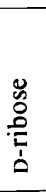 & $\begin{array}{l}\ddot{0} \\
0 \\
0 \\
\dot{0} \\
\dot{0}\end{array}$ & 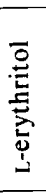 \\
\hline \multirow[t]{8}{*}{ B abortus } & 1 & 544 & $\begin{array}{l}\text { Neotype and biotype } \\
\text { reference }\end{array}$ & + & + & + & - & - & - & - & + & + & + & + & + \\
\hline & 2 & $86 / 8 / 59$ & Biotype reference & + & + & + & - & - & - & - & + & + & + & + & + \\
\hline & 3 & Tulya & Biotype reference & + & + & + & - & - & - & - & + & + & + & + & + \\
\hline & 4 & $\begin{array}{l}292 \\
\text { R2106 }\end{array}$ & Biotype reference & + & + & + & - & - & - & - & + & + & + & + & + \\
\hline & 5 & $\begin{array}{l}\text { B3196 } \\
870\end{array}$ & Biotype reference & + & + & + & - & - & - & - & + & + & + & + & + \\
\hline & $\begin{array}{l}6 \\
7\end{array}$ & $\begin{array}{l}870 \\
63175\end{array}$ & $\begin{array}{l}\text { Biotype reference } \\
\text { Biotype reference }\end{array}$ & + & + & + & - & - & - & - & $\begin{array}{l}+ \\
+\end{array}$ & + & + & + & + \\
\hline & 8 & None available & Biotype reference & + & + & + & - & - & - & - & $T$ & + & + & + & + \\
\hline & 9 & C-68 & & + & + & + & - & - & - & - & + & + & + & + & + \\
\hline \multirow{3}{*}{ B. melitensis } & 1 & $16 \mathrm{M}$ & $\begin{array}{l}\text { Neotype and biotype } \\
\text { reference }\end{array}$ & + & + & + & - & - & - & - & - & - & - & + & + \\
\hline & 2 & $63 / 9$ & Biotype reference & + & + & + & - & - & - & - & $\begin{array}{l}- \\
-\end{array}$ & - & $\begin{array}{l}- \\
-\end{array}$ & $\begin{array}{l}+ \\
+\end{array}$ & $\begin{array}{l}+ \\
+\end{array}$ \\
\hline & 3 & $\begin{array}{l}\text { Ether } \\
1330\end{array}$ & $\begin{array}{l}\text { Biotype reference } \\
\text { Neotype and biotype }\end{array}$ & $\begin{array}{l}+ \\
+\end{array}$ & $\begin{array}{l}+ \\
-\end{array}$ & $\begin{array}{l}+ \\
-\end{array}$ & $\begin{array}{l}- \\
+\end{array}$ & $\begin{array}{c}- \\
+\end{array}$ & $\overline{+}$ & $\overline{+}$ & + & + & + & + & + \\
\hline \multirow{4}{*}{ B. suis } & & 1330 & $\begin{array}{l}\text { Neotype and biotype } \\
\text { reference }\end{array}$ & & & & & & & & & & & & \\
\hline & 2 & Thomsen & Biotype reference & - & - & + & + & + & + & $\begin{array}{l}+ \\
+\end{array}$ & $\begin{array}{l}+ \\
-\end{array}$ & $\begin{array}{l}+ \\
-\end{array}$ & $\begin{array}{l}+ \\
+\end{array}$ & + & $\begin{array}{l}+ \\
+\end{array}$ \\
\hline & $\begin{array}{l}3 \\
4\end{array}$ & $\begin{array}{l}686 \\
40\end{array}$ & $\begin{array}{l}\text { Biotype reference } \\
\text { Biotype reference }\end{array}$ & $\begin{array}{l}+ \\
-\end{array}$ & $\begin{array}{l}- \\
-\end{array}$ & $\begin{array}{l}+ \\
+\end{array}$ & $\begin{array}{l}+ \\
+\end{array}$ & $\begin{array}{l}+ \\
+\end{array}$ & $\begin{array}{l}+ \\
+\end{array}$ & + & - & - & + & + & + \\
\hline & 5 & $\begin{array}{l}\text { None available } \\
6390\end{array}$ & $\begin{array}{l}\text { Biotype reference } \\
\text { Neotype reference }\end{array}$ & + & + & + & - & - & - & - & - & - & - & - & - \\
\hline
\end{tabular}


TABLE 4. Strain and ATCC numbers of Brucella species

\begin{tabular}{l|c|c}
\hline \multicolumn{1}{c|}{ Species } & Strain no. & ATCC no. \\
\hline B. abortus & 544 & 23488 \\
B. suis & 1330 & 23444 \\
B. melitensis & $16 \mathrm{M}$ & 23452 \\
B. ovis & 6390 & 25840 \\
\hline
\end{tabular}

scope nor number of these differences is regarded as sufficient to justify the recognition of subspecies. However, the characteristics by which these strains differ from the type or neotype strains are useful as identification markers for epidemiological investigations, and such strains have been accomodated into the classification schema as biotypes. The strains recommended as references for the biotypes are listed in table 5 .

$B$. abortus biotype 1 was described originally by Huddleson (10), biotype 2 by Wilson (31), biotype 3 by Van der Schaaf and Roza (34), and all the remaining biotypes of $B$. abortus and the biotypes of $B$. melitensis were described by the Subcommittee on the Taxonomy of the Genus Brucella (27). $B$. suis biotype 1 originally was described by Huddleson (10), biotype 2 by Wilson (31), biotype 3 by Meyer and Cameron (21), biotype 4 by Meyer (16), and biotype 5 by Renoux (24).

The first of the several microorganisms that eventually were placed in the genus Brucella was isolated by Bruce (3) from patients dying of Malta (undulant) fever. Because undulant fever was difficult to differentiate symptomatically and clinically from other fevers then endemic in the countries of the Mediterranean littoral, physicians of the day were not entirely convinced that it was a separate clinical entity. Consequently, they were dubious about the causal role of this newly isolated organism. Bruce (4) accumulated the necessary evidence to satisfy his critics on both counts, and in 1893 he named the organism Micrococcus melitensis so as to reflect its morphology and its original geographical site of isolation, the Island of Malta. (Melitensis is a latinized adjective for Malta, which in turn is a modernization of the island's historical name of Melita, named either by the Greeks [meli, sweet] because of the superb quality of the honey produced there or by the Phoenicians [meli, shelter] because of its life-saving location for shipwreck victims [8].)

The second of the organisms that later was to become a member of the genus Brucella was isolated by Bang (2) from the uterine exudate of a cow with clinical indications of an impending abortion. Bang referred to the organism simply as the abortion bacillus, and his contemporaries sometimes called it Bang's bacillus. The name Bacterium abortus first was used by Schmidt and
Weis (25) in a textbook on bacteriology.

The formation of the genus Brucella (Meyer and Shaw, 1920) and the inclusion therein of $\boldsymbol{M}$. melitensis (B. melitensis) and of $B$. abortus $(B$. abortus) originated from Evans' findings that $M$. melitensis, instead of being a coccus, was a short rod with rounded ends and was culturally, biochemically, and serologically all but indistinguishable from $B$. abortus.

After the introduction by Huddleson (10) of more precise methods of identifying species in this genus, the organism isolated by Traum (30) from aborted swine fetuses, and which was considered to be a porcine variety of $B$. abortus, was advanced to species rank as B. suis. From 1929 until the early 1960's there were conflicting concepts of this genus. The most frequently reiterated and widely held concept was first expressed by Wilson (31). After examining some 300 strains by the then newly introduced determinative methods he concluded that "though it is possible to distinguish broadly between the three main types (species) within the group (genus) there are no hard and fast lines of demarcation between them, and the existence of transitional forms is sufficiently frequent to suggest that specific features are subject to change with environmental conditions." Because of the reported numbers of atypical, transitional, and aberrant strains, Renoux (23) considered the differences between strains to be insufficient to justify a multiple species classification schema within this genus and suggested there was only one species with an indefinite and almost infinite number of variants. Stableforth (26) tabulated the combination of characteristics reported for the atypical

T $\mathrm{ABLE}$ 5. Brucella strains recommended as references for the biotypes

\begin{tabular}{l|c|l|c}
\hline \multicolumn{1}{c|}{ Species } & $\begin{array}{c}\text { Bio- } \\
\text { type } \\
\text { no. }\end{array}$ & $\begin{array}{c}\text { Strain } \\
\text { designation }\end{array}$ & $\begin{array}{c}\text { ATCC } \\
\text { no. }\end{array}$ \\
\hline B. abortus & 1 & 544 & 23488 \\
& 2 & $86 / 8 / 59$ & 23449 \\
& 3 & Tulya & 23450 \\
& 4 & 292 & 23451 \\
& 5 & B-3196 & 23452 \\
& 6 & 870 & 23453 \\
& 7 & 63175 & 23454 \\
& 8 & Not available & \\
& 9 & C-68 & 23455 \\
& 1 & $16 \mathrm{M}$ & 23456 \\
& 2 & $63 / 9$ & 23457 \\
B. suis & 3 & Ether & 23458 \\
& 1 & 1330 & 23444 \\
& 2 & Thomsen & 23445 \\
& 3 & 686 & 23446 \\
& 4 & 40 & 23447 \\
& 5 & Not available & \\
\hline
\end{tabular}


cultures and concluded that Brucella strains formed a more or less continuous series with differences between strains being quantitative rather than qualitative.

Even though the species shared many similarities and seemingly had but few measurable distinguishing features, the fact remained that each species had a preferential affinity for a different animal host. Strains identifiable as $B$. abortus almost invariably were isolated from cattle, $B$. suis was isolated from swine, and $B$. melitensis was isolated from sheep and goats. This preferential affinity for different hosts and other speciesrelated in vivo differences led some investigators to hold an alternative concept of this genus, i.e., that it did consist of multiple species, but the differential tests themselves were inadequate to distinguish and separate the member organism (15).

By using manometric techniques to measure oxidative utilization of an array of separate amino acid and carbohydrate substrates, Meyer and Cameron $(19,20)$ and Meyer (13) found that there are distinct qualitative differences between the species in this genus. Each species has a characteristic and definitive metabolic pattern as indicated by its differential utilization of the various substrates. They also found that strains previously described as atypical, aberrant, or transitional, according to results of the conventional determinative tests, had a metabolic pattern characteristic for one of the recognized species. Comparative examination with Brucella phage revealed that only strains with the pattern of metabolism of $B$. abortus were susceptible to lysis at routine test dilution of the phage (14).

In 1962, the Subcommittee on the Taxonomy of the Genus Brucella expanded the definition of each of the species to include descriptions of their oxidative, metabolic patterns and response to phage exposure as well as characteristics measured by the conventional determinative methods (27).

In addition to the three organisms, $B$. abortus, $B$. suis, and $B$. melitensis (sometimes referred to as the three classical species), placed in Brucella since its formation, this genus also includes the species $B$. neotomae Stoenner and Lackman and $B$. ovis Buddle.

B. neotomae was isolated and described in 1957 (29) and admitted to the genus as an additional species in 1966 (Subcommittee Report, 11).

The organism(s) known as $B$. ovis initially was described as a mutant of $\boldsymbol{B}$. melitensis by Buddle and Boyes (6). Buddle (5) later considered it to be a spearate species and suggested that it be known as $B$. ovis. This organism differs markedly in several characteristics by which organisms are identified as Brucella at the generic level, and it was only after Hoyer and McCullough (11) showed it to be $94 \%$ similar to other brucellae by deoxyribonucleic acid hybridization studies that it was admitted to the genus.

Like other members of this genus, $B$. ovis has a characteristic metabolic pattern (17).

Except for $B$. neotomae, the original isolates that established each of the five recognized Brucella species have been lost. Although at least two strains of $B$. suis that were isolated by Huddleson (ATCC 4312 and 4313) are extant, there is no evidence that either of these strains was used by Huddleson in his original description of $B$. suis. Furthermore, neither of these strains is in suitable condition to serve as the neotype. Consequently, Morgan's strain 1330 (originally isolated by W. W. Spink from swine) was designated as the neotype. The determinative tests upon which the original species descriptions were based are still used as part of the array of procedures recommended for identifying Brucella species. The results of these tests indicate that the descriptions of the strains being proposed as neotypes are identical to the descriptions of the original isolates. Each strain also fits the expanded species descriptions, and their taxonomic niches integrate well with the prevailing concept of this genus.

Data on the organism described as a new species, B. canis Carmichael and Brunner, have not been included in this report. At its 1970 meeting the Subcommittee accepted this organism as a species only on a provisional basis. There is no question of its being properly identified as a member of the genus Brucella. There is, however, doubt about the taxonomic level at which it should be included in the classification schema, and a greater body of information on this organism will have to be gathered before it is possible to decide whether it should be considered a separate species or a biotype of an existing species.

\section{LITERATURE CITED}

1. Alton, G. G., and L. M. Jones. 1967. Laboratory techniques in brucellosis. W.H.O. Monogr. Ser. 55. World Health Organization, Geneva.

2. Bang, B. 1897. The etiology of epizootic abortion. J. Comp. Pathol. 10:125-149.

3. Bruce, D. 1887. Note on the discovery of a microorganism in Malta fever. Practitioner 39:161-170.

4. Bruce, D. 1893. Sur une nouvelle forme de fievre. Ann. Inst. Pastour (Paris) 7:289-304.

5. Buddle, M. B. 1956. Studies on Brucella ovis (n. sp.). A cause of genital disease of sheep in New Zealand and Australia. J. Hyg. 54:351-364.

6. Buddle, M. B., and B. W. Boyes. 1953. A Brucella mutant causing genital disease in sheep in New Zealand. Aust. Vet. J. 29:145-153.

7. Carmichael, L. E., and D. W. Bruner. 1968. Characteristics of a newly recognized species of Brucella 
responsible for infectious canine abortions. Cornell Vet. 48:579-592.

8. Charnock, R. S. 1859. Local etymology: a derivative dictionary of geographic names. Houston Wright, London.

9. Evans, A. C. 1918. Further studies on Bacterium abortus and related bacteria. II. A comparison of Bacterium abortus and Bacterium bronchisepticus and with the organism which causes Melta fever. $\mathbf{J}$. Infect. Dis. 22:580-593.

10. Huddleson, I. F. 1929. The differentiation of the species in the genus Brucella. Mich. State Coll. Agr. Exp. Sta. Tech. Bull. No. 100. East Lansing, Mich.

11. International Committee on Nomenclature of Bacteria, Subcommittee on the Taxonomy of Brucella. 1971. Minutes of Meeting, 7 August 1970. Int. J. Syst. Bacteriol. 21:126-128.

12. Meyer, K. F., and E. B. Shaw. 1920. A comparison of the morphologic, cultural, and biochemical characteristics of $B$. abortus and $B$. melitensis. J. Infect. Dis. 27:173-184.

13. Meyer, M. E. 1961. Metabolic characterization of the genus Brucella. III. Oxidative metabolism of strains that show anomalous characteristics by conventional determinative methods. J. Bacteriol. 82:401-410.

14. Meyer, M. E. 1961. Metabolic characterization of the genus Brucella. IV. Correlation of oxidative metabolic pattern and phage susceptibility. J. Bacteriol. 82:950-953.

15. Meyer, M. E. 1964. The epizootiology of brucellosis and its relationship to the identification of Brucella organisms. Amer. J. Vet. Res. 25:553-557.

16. Meyer, M. E. 1964. Species identity and epidemiology of Brucella strain isolated from Alaskan Eskimos. J. Infect. Dis. 114:169-173.

17. Meyer, M. E. 1960. Phenotypic comparison of Brucella ovis to the DNA-homologous Brucella species. Amer. J. Vet. Res. 30:1957-1964.

18. Meyer, M. E., and H. S. Cameron. 1958. Species metabolic patterns within the genus Brucella. Amer. J. Vet. Res. 72:754-758.

19. Meyer, M. E., and H. S. Cameron. 1961. Metabolic characterization of the genus Brucella. I. Statistical evaluation of the oxidative rates by which type 1 of each species can be identified. J. Bacteriol. 82:387-395.

20: Meyer, M. E., and H. S. Cameron. 1961b. Metabolic characterization of the genus Brucella. II. Oxidative metabolic patterns of the described bi- otypes. J. Bacteriol. 82:396-400.

21. Meyer, M. E., and H. S. Cameron. 1963. Identification of the causative agents and epidemiology of porcine brucellosis. Bull. W.H.O. 28:499-503.

22. Morgan, W. J. B., and S. G. M. Gower. 1966. Techniques in the identification and classification of Brucella, p. 35-40. In B. M. Gibbs and F. A. Skinner (ed.), Identification methods for microbiologists. Academic Press Inc., London.

23. Renoux, G. 1958. La notion d'espece dans le genere Brucella. Ann. Inst. Pasteur (Paris) 94:179-206.

24. Renoux, G., and A. Philippon. 1969. Position taxonomique dans de genre Brucella de bacteries isolees de brebis et de vaches. Ann. Inst. Pasteur 117:524-528.

25. Schmidt, J., and F. Weis. 1902. Die Bakterien. Naturhistorische Grundlage Fur Das Bakteriologische Stadium. Verlag von Gustav Fischer, Jena.

26. Stableforth, A. W. 1959. Brucellosis, p. 53-159. In A. W. Stableforth and I. A. Galloway (ed.), Infectious Diseases of Animals. I. Diseases Due to Bacteria. Butterworth Scientific Publications, London.

27. Stableforth, A. W., and L. M. Jones. 1962. Report of the Subcommittee on Taxonomy of the Genus Brycekka. Int. Bull. Bacteriol. Nomencl. Taxon. 13:145-158.

28. Stinebring, W. R., and W. Braun. 1959. Brucella phage. J. Bacteriol. 78:736-737.

29. Stoenner, H. G., and D. B. Lackman. 1957. A new species of Brucella isolated from the desert wood rat, Neotoma lepida. Thomas. Amer. J. Vet. Res. 69:947-951.

30. Traum, J. 1914. Report of the Chief of the Bureau of Animal Industry, U. S. Department of Agriculture, p. 30. U. S. Department of Agriculture, Washington, D. C

31. Wilson, G. S. 1933. The classification of the Brucella group: a systematic study. J. Hyg 33:516 -541 .

32. Wilson, G. S., and A. A. Miles. 1932. The serological differentiation of smooth strains of the Brucella group. Brit. J. Exp. Pathol. 13:1-13.

33. World Health Organization. 1971. Joint FAO/ WHO Expert Committee on Brucellosis. Fifth report. Food and Agricultural Oranization (United Nations) Agricultural Studies, no. 85. Geneva.

34. Van der Schaaf, A., and M. Roza. 1940. Brucellosis en onchocerciasis in verband met een chronish gewrichtelijden bij runderen. Ned. Ind. B1. Diergenseek 52:1-20. 